Schiener, E. J. 1977: Sedimentological observations on early Cretaceous sediments in eastern parts of the Nûgssuaq embayment. Rapp. Grønlands geol. Unders. 79, 45-61.

Institut for almen Geologi, University of Copenhagen,

$\emptyset$ stervoldgade 10,

$D K-1350$ Copenhagen $K$.

\title{
New investigations of Tertiary lavas and dykes in the area around Disko Fjord, South Disko, central West Greenland
}

\section{Finn Ulff-Møller}

The purpose of the summer's field work was twofold: (a) to search for native iron and sulphide mineral assemblages in the northern extension of the Kitdlit dyke (Fundal, 1975; Pedersen, 1977a \& 'a' in figs $10 \& 11$ ) and other related (sediment contaminated) dykes, and (b) to map the surrounding area as a contribution to the map sheet Diskofjord ( $69 \mathrm{~V}$. 1 $\mathrm{N}$, fig. 2). About $600 \mathrm{~km}^{2}$ were mapped in detail and $1500 \mathrm{~km}^{2}$ briefly surveyed.

\section{Regional geology}

Amphibolite facies gneisses and metasediments of Precambrian age, constituting the north-south trending Disko gneiss ridge, are exposed where deep valleys transect the plateau basalts.

In places the Precambrian rocks are overlain by Cretaceous-Tertiary sediments which appear in a few exposures of arkose on the eastern flank of the gneiss ridge.

A sequence of Lower Tertiary plateau basalt rests directly on Precambrian rocks or the overlying sediments. Most basalts belong to the Rinks Dal Member of the Maligât Formation (for stratigraphical subdivision of the lava sequence see Hald \& Pedersen, 1975; Pedersen, 1975) but in the west (loc. 1, fig. 10) they are overlain by at least $160 \mathrm{~m}$ of lavas of the Nordfjord Member. Loose blocks of characteristic andesitic rocks indicate that lavas of the Niaqússat Member were present at slightly higher stratigraphical levels, being removed by later erosion. No olivine-rich lavas of the underlying Vaigat Formation have been observed. The total stratigraphic thickness of the lava sequence within the area is about 1.5 $\mathrm{km}$.

The lavas of the Rinks Dal Member form a monotonous sequence of mainly plagioclase-(olivine) glomerophyric tholeiitic basalts with subordinate amounts of aphyric or slightly plagioclase microporphyric basalts and only very few olivine-rich tholeiitic basalts. Slight differences in flow morphology and in weathering colour, visible in good light, have made it possible to trace several marker horizons over long distances. This infers considerable lateral uniformity of the lava sequence. East of the gneiss ridge the lowermost exposed lavas of the Rinks Dal Member grade into a sequence of pillow breccia. 


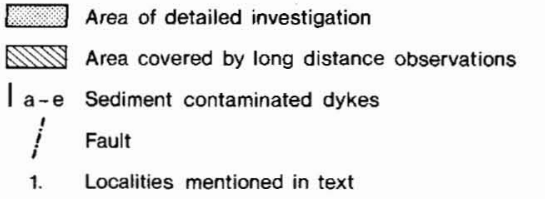

Fig. 10. Sketch map showing the investigated area and the sediment contaminated dykes.

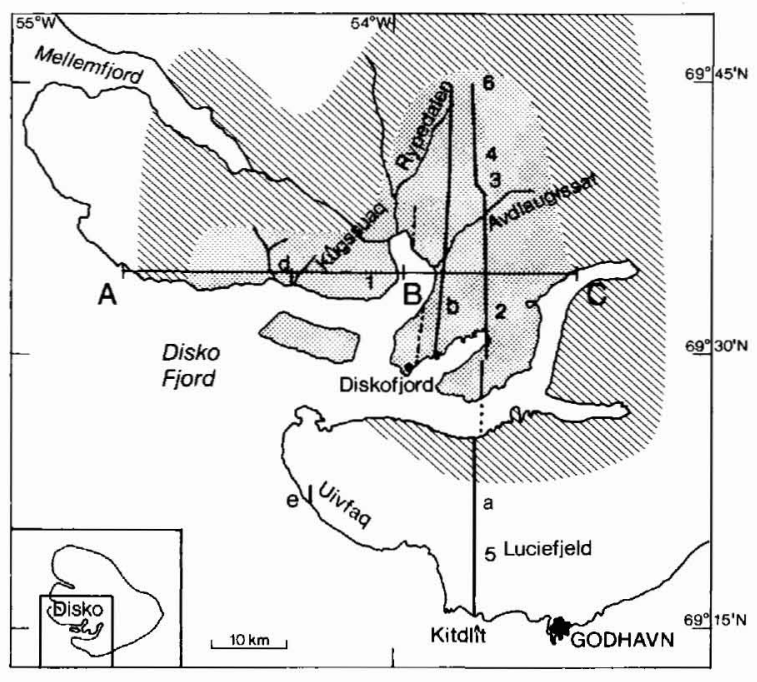

As in the Mellemfjord area (Pedersen, 1977b) the Nordfjord Member comprises strongly sediment contaminated lavas and slightly or uncontaminated plagioclase-olivine glomerophyric lavas.

In the east the lavas are horizontal or dip slightly WSW. Further west the dip increases but no more than a few degrees.

Apart from the fault east of the Diskofjord settlement with a vertical displacement of 200-300 m (figs $10 \& 11$ ), only faults with displacements less than $20 \mathrm{~m}$ have been observed.

The present mountainous landscape is composed of two major topographical elements. The older one forms a gently undulating surface which slopes west or south-west. The maximum relief was about $500 \mathrm{~m}$. This land surface is thought to be post-eruptional but

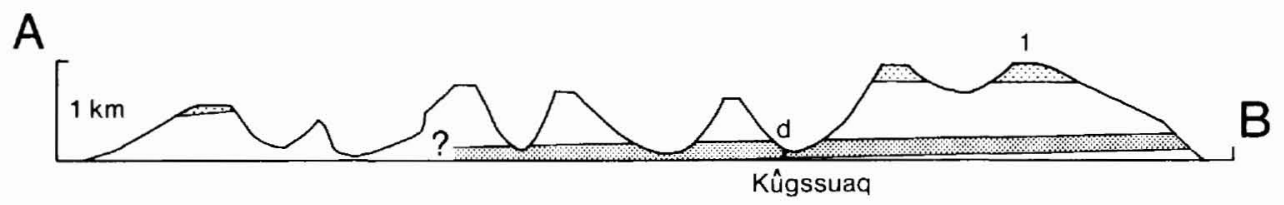

Nordfjord member

Rinks Dal member with a marker honzon

Gneiss/pillow breccia

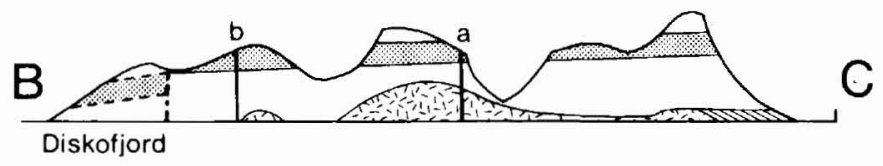

$10 \mathrm{~km}$

Fig. 11. Schematic profile section through the area around Disko Fjord. For position see fig. 10. 
pre-Quaternary. An old land surface can also be traced on north-west Disko. Relics of the old land surface usually form smaller plateaus on top of the mountains. The younger topographical element comprises deeply transected $U$-shaped valleys which have increased the maximum relief to about 1000-1200 m. The younger element was formed during Quaternary glaciations and is dominant.

\section{Sediment contaminated dykes}

In addition to the well-known dyke at Uivfaq (Bøggild, 1953) three contaminated dykes (a, b, c, fig. 10) were found in 1974 (Ulff-Møller, 1975; Pedersen, 1977a). The existence of a fourth dyke was inferred from samples at the Geological Museum (Copenhagen) collected by $\mathbf{H}$. Rink in the last century. This dyke was rediscovered this summer (d, fig. 10). All these dykes are probably closely related to the Niaqússat Member volcanism.

(a) The Kitdlit dyke is described by Fundal (1975) and Pedersen (1977a; in press). A sulphide lens and some branching bodies of native iron in dolerite were collected from this dyke (loc. 2, fig. 10) in 1974 (Ulff-Møller, 1978). Of all dykes studied this displays the most severe signs of contamination and reduction.

The dyke is vertical, strikes north-south and was intruded near the crest of the Disko gneiss ridge. At present the dyke is known to extend for $55 \mathrm{~km}$ but it is likely to continue further north for a considerable distance. It has a rectilinear course with only minor 'en echelon' and 'en bayonnet' displacements. In the southern part of the area the dyke is generally 6-8 m wide but north of the Avdlaugíssat valley it widens to $15-20 \mathrm{~m}$.

This summer locality 2 (fig. 10) was revisited and mineral assemblages dominated by native iron and cohenite $\left(\mathrm{Fe}_{3} \mathrm{C}\right)$, both as dissemination in the dolerite and as massive bodies, were collected. One of the largest massive bodies appeared to form the lower part of the sulphide lens described by Ulff-Møller (1978). These mineral assemblages are similar to the large blocks of iron from the dyke at Uivfaq (Löfquist \& Benedicks, 1940).

At locality 3 a cumulate zone of branching bodies of native iron of a few centimetres across was found where the contact dip locally deviates from vertical. The cumulate zone contains iron bodies associated with little troilite and some where troilite constitutes a considerable part of the aggregate and may thus show some similarity to the cumulate zones of the Hammers Dal Complex on north-west Disko (Ulff-Møller, 1977) although the spatial distribution is not so simple.

At locality 4 several loose blocks of dolerite containing native iron indicate that a similar cumulate zone existed slightly above the present level of erosion.

An additional cumulate zone occurs at Luciefjeld (loc. 5, fig. 10).

These cumulate zones show that the intruding magma, like that forming the marginal dolerite of the Hammers Dal Complex, carried bodies of native iron, but that they settled out and are found almost exclusively in favourable depositional environments.

At locality 6 the dyke is displaced 'en echelon'. The main dyke contains a poorly delimited andesitic core with small amounts of native iron. Its similarity to other composite intrusions like those of the Hammers Dal Complex, together with the absence of an andesitic core in the southern part of the dyke, could be taken as an indication that the magma intruded from the north. 
In the central part of the displaced dyke which is about $3 \mathrm{~m}$ wide and which probably wedges out downwards, a vertical zone of dolerite rich in disseminated troilite occurs. In the upper part of the dyke this mineralized zone contains $0.5-1 \mathrm{~cm}$ sized, troilite-rich bodies which each contain a minor, iron-rich body in its lower part. At a lower level the mineralized zone is penetrated by a $1 \mathrm{~cm}$ thick crack, parallel to the contacts of the dyke, which contains an overgrowth of approximately equal parts of iron and cohenite with subordinate amounts of troilite. In the author's opinion this indicates that the iron and cohenite-rich mineral assemblages were formed by solidification of iron-carbon melts which were transported with the magma, and that they still existed as melts at temperatures at or below that at which the basaltic magma had solidified to such a degree that cracks could develop.

Glass formed by quenching of the magma, occurring in thin veins in the wall rock, contains numerous elongate blebs (10-100 microns) of an immiscible sulphide melt of approximately eutectic composition in the Fe-FeS system similar to glass from the dyke at Luciefjeld (Pedersen, in press). It is surprising, however, that no blebs representing an iron-carbon melt have been observed in either case.

At all the localities where native iron has been found, the dolerite always has a tar-like smell on fresh fracture surfaces and loose blocks in which the iron is totally weathered out.

(b) A few kilometres north-east of the Diskofjord settlement another, slightly sediment contaminated dyke occurs (b, figs $10 \& 11$ ). The dyke has only been examined in detail in the south, but it is known to continue northwards for at least $28 \mathrm{~km}$. In contrast to the Kitdlit dyke, sediment xenoliths are very rare in this dyke, but a $5 \mathrm{~m}$ sized inclusion of medium-grained dolerite indicates that the transportation ability of the magma was considerable.

Glass from a rapidly chilled vein in the wall rock shows that the magma contained microphenocrysts of olivine with inclusions of opaque spinel (probably chromian). Numerous phenocrysts of pyroxene and plagioclase probably formed during cooling also occur. No sulphide blebs were observed.

(c) On the north coast of Mellemfjord, at Sarqardlit ilordlit, another slightly sediment contaminated dyke occurs. It is vertical, strikes north-south and is only known to extend for about $1 \mathrm{~km}$. At depth it is about $10 \mathrm{~m}$ wide, but upwards it narrows out to only $1 \mathrm{~m}$. At all levels the dyke is rich in vesicles, some being filled with zeolites. Glass representing chilled magma contains olivine microphenocrysts and subordinate amounts of sulphide blebs consisting of pyrrhotite, pentlandite and chalcopyrite, but no native iron. Obviously the dyke was less reduced than the Kitdlît dyke.

(d) A composite dyke was found at the entrance of the Kûgssuaq valley (d, figs. 10 \& 11). This dyke is likely to be the source of a sample collected by H. Rink in the last century. Like those dykes described it is vertical and strikes north-south and at present it is only known to be exposed on the beach. It is about $4 \mathrm{~m}$ wide and extends for about $10 \mathrm{~m}$. It is composed of a marginal dolerite of very variable thickness $(0.2-1 \mathrm{~m})$ due to the irregular contacts. Inwards the dolerite grades into a central andesitic rock through a $10-20 \mathrm{~cm}$ wide transition zone consisting of a hybrid rock. In contrast to the irregular contacts the transition zone is approximately planar. The dolerite appears aphyric, but the magma may have contained 
olivine microphenocrysts at the time of intrusion. Glass was formed at certain places along the contacts but has later been altered totally. The central andesitic part is $2.5 \mathrm{~m}$ wide and contains numerous $1-10 \mathrm{~cm}$ sized, highly recrystallized and chemically equilibrated sediment xenoliths consisting mainly of plagioclase and graphite. These are situated in a matrix containing several phenocrysts of olivine and probably orthopyroxene (up to $1 \mathrm{~cm}$ ). No macroscopic iron was observed in either of the rocks.

\section{Acknowledgements}

The field work was carried out as a part of a project supported by the Danish Natural Science Research Council. The Direction of the Arctic Station is thanked for transport assistance by the ship Porsild.

\section{References}

Bøggild, O. B. 1953: The mineralogy of Greenland. Meddr Grønland 194, 4, $422 \mathrm{pp}$.

Fundal, E. 1975: The Uivfaq dike and related hybrid dikes from southern Disko, West Greenland. Meddr Grønland 195, 28 pp.

Hald, N. \& Pedersen, A. K. 1975: Lithostratigraphy of the early Tertiary volcanic rocks of central West Greenland. Rapp. Grønlands geol. Unders. 69, 17-24.

Löfquist, H. \& Benedicks, C. 1940: Det stora Nordenskiöldska järnblocket från Ovifaq, dess mikrografi och metallurgi. Jernkont. Annls 124, 633-685.

Pedersen, A. K. 1975: New mapping in north-western Disko 1972. Rapp. Grønlands geol. Unders. 69, 25-32.

Pedersen, A. K. 1977a: Dyke intrusions along the south coast of Disko. Rapp. Grønlands geol. Unders. 81, 57-67.

Pedersen, A. K. 1977b: Tertiary volcanic geology of the Mellemfjord area, south-west Disko. Rapp. Grønlands geol. Unders. 81, 35-51.

Pedersen, A. K. in press: Basaltic glass with high-temperature equilibrated native iron-bearing immiscible sulphide bodies from Disko, central West Greenland. Submitted to Contributions to Mineralogy and Petrology.

Ulff-Møller, F. 1975: High-temperature pyrrhotite and telluric iron mineralisations in western Disko, central West Greenland. Rapp. Grønlands geol. Unders. 75, 51-53.

Ulff-Møller, F. 1977: Native iron-bearing intrusions of the Hammers Dal Complex, north-west Disko. Rapp. Grønlands geol. Unders. 81, 15-33.

Ulff-Møller, F. 1978: Sulfidlinsen fra Syd Disko. Unpublished prize dissertation. University of Copenhagen.

Geologisk Museum, University of Copenhagen, Oster Voldgade 10, $D K-1350$ Copenhagen $K$. 